\title{
CLIMATIC POTENTIAL FOR WINE GRAPE PRODUCTION IN THE TROPICAL NORTH REGION OF MINAS GERAIS STATE, BRAZIL ${ }^{1}$
}

\author{
MARCO ANTÔNIO FONSECA CONCEIÇÃO² \& JORGE TONIETTO ${ }^{3}$
}

\begin{abstract}
The tropical north region of Minas Gerais State is one of the least developed of Brazil and viticulture could be an alternative to develop its agriculture zone. The objective of this work was to evaluate the climatic potential of that region for wine grape production. The evaluations were carried out applying the Multicriteria Climatic Classification System (Geoviticulture MCC System), that utilizes three reference climatic indexes (Dryness Index - DI, Heliothermal Index - HI and Cool Night Index - CI). Three locations - Pirapora (17 $\left.21^{\prime} \mathrm{S}, 44^{\circ} 56^{\prime} \mathrm{W}, 489 \mathrm{~m}\right)$, Montes Claros (16 $\left.43^{\prime} \mathrm{S}, 43^{\circ} 52^{\prime} \mathrm{W}, 647 \mathrm{~m}\right)$ and Diamantina $\left(18^{\circ} 15^{\prime} \mathrm{S}, 43^{\circ} 36^{\prime} \mathrm{W}, 1297 \mathrm{~m}\right)$ - and two potential production cycles along the year - October to March (spring-summer period) and April to September (autumn-winter period) - were evaluated. The results showed that in the spring-summer period (SS period) Pirapora and Montes Claros presented a 'humid, very warm and with warm nights' of viticultural climate, according to MCC System. For the autumn-winter period (AW period), those two regions presented a 'moderately dry, warm and with temperate nights' according to MCC System. Otherwise, the Diamantina SS period presented a 'humid, temperate warm and with temperate nights' viticultural climate. In the AW period, the Diamantina climatic condition values represent a 'subhumid, temperate and with cool nights' viticultural climate. Based on those results it can be concluded that the North Region of Minas Gerais State has a great climatic potential to became a grape-growing region for wine-making, specially in the autumn-winter period.
\end{abstract}

Index terms: viticulture, climatic zoning, biometeorological index.

\section{POTENCIAL CLIMÁTICO PARA A PRODUÇÃO DE UVAS PARA A ELABORAÇÃo DE VINHOS FINOS NO NORTE DE MINAS GERAIS}

RESUMO - A região Norte do Estado de Minas Gerais é uma das mais pobres do País, e a viticultura pode ser uma alternativa para o desenvolvimento rural dessa região. O objetivo do trabalho foi o de avaliar a potencialidade climática dessa região, visando à produção de uvas para a elaboração de vinhos finos. A metodologia utilizada foi a do Sistema de Classificação Climática Multicritério (CCM) Geovitícola, que utiliza três índices climáticos

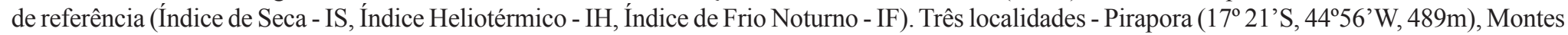
Claros ( $\left.16^{\circ} 43^{\prime} \mathrm{S}, 43^{\circ} 52^{\prime} \mathrm{W}, 647 \mathrm{~m}\right)$ e Diamantina (18 $\left.{ }^{\circ} 15^{\prime} \mathrm{S}, 4^{\circ} 36^{\prime} \mathrm{W}, 1297 \mathrm{~m}\right)$, e dois períodos de produção potencial durante o ano - outubro-março (período de primavera-verão) e abril-setembro (período de outono-inverno) foram avaliados. Os resultados mostraram que, no período de primaveraverão (período PV), Pirapora e Montes Claros apresentaram um clima vitícola "úmido, muito quente e com noites quentes", segundo os índices IS, IH e IF do Sistema CCM, respectivamente. No período de outono-inverno (período OI), essas regiões apresentaram um clima vitícola "moderamente seco, quente e de noites temperadas", segundo o Sistema CCM. Diamantina apresentou, no período PV, um clima vitícola "úmido, temperado quente e com noites temperadas". Já no período OI, a condição climática de Diamantina corresponde a um clima vitícola "subúmido, temperado e com noites frias”, segundo o sistema CCM. Com base nessas avaliações, pode-se concluir que a região Norte de Minas Gerais apresenta um grande potencial para a produção de uvas destinadas à elaboração de vinhos finos, em particular no período de outono-inverno.

Termos para indexação: viticultura, zoneamento climático, índices biometeorológicos.

\section{INTRODUCTION}

The Vitis vinifera grape production for wine-making in Brazil is restricted to the southern regions, in the subtropical area, and to the region of Petrolina, in the tropical area, localized in the São Francisco Valley the northeast of Brazil. In the southern regions, because of the low temperatures in autumn-winter period, the grapevines can produce only once a year, with the harvest occurring in the summer period.

Tonietto \& Carbonneau (2004) developed the Multicriteria Climatic Classification System (MCC System) for grape growing regions. The MCC System is based on three indexes. The Heliothermal Index (HI) provides information about the heliothermal potential and varies from values of $1500^{\circ} \mathrm{C}$ (very cool) to values $>3000^{\circ} \mathrm{C}$ (very warm). The Cool Night Index $(\mathrm{CI})$ represents the minimum average air temperature of the last month of the growing period and varies from values of $12^{\circ} \mathrm{C}$ (very cool nights) to values $>18^{\circ} \mathrm{C}$ (warm nights). The Dryness Index (DI) indicates the potential water availability in soil and varies from values $>150 \mathrm{~mm}$ (humid) to values of $-100 \mathrm{~mm}$ (very dry).

According to the MCC System, Serra Gaucha, the main southern production region, presents a humidity (DI $>150 \mathrm{~mm})$, temperate warm $\left(2100^{\circ} \mathrm{C}<\mathrm{HId} " 2400^{\circ} \mathrm{C}\right)$ and with temperate nights $\left(14^{\circ} \mathrm{C}<\mathrm{CId} " 18^{\circ} \mathrm{C}\right)$ viticultural climate (Tonietto \& Carbonneau, 2004). On the other hand, the Petrolina region presents a viticultural climate with intra-annual variability, making grape production possible in different periods of the year. According to the MCC System, the region has a very warm $\left(\mathrm{HI}>3000^{\circ} \mathrm{C}\right)$ with warm nights $\left(\mathrm{CI}>18^{\circ} \mathrm{C}\right)$ viticultural climate and it can be classified, according to the Dryness Index (DI), as a sub-humid $(50 \mathrm{~mm}<$ DId" $150 \mathrm{~mm})$, moderately dry $(-100 \mathrm{~mm}<$ DId" $50 \mathrm{~mm})$ or very dry climate (DId"-100mm), depending on the period of the year (Tonietto \& Carbonneau, 2004).

The tropical north region of Minas Gerais State is one of the least developed of Brazil and currently presents a small table grape production. The objective of this work was to evaluate the climatic potential of that region for wine grape production, believing that winemaking viticulture could be an alternative to develop its agriculture zone.

\section{MATERIAL AND METHODS}

The present work was based on historical average meteorological data from three regions in the north of Minas Gerais State - Pirapora ( $\left.17^{\circ} 21^{\prime} \mathrm{S}, 44^{\circ} 56^{\prime} \mathrm{W}, 489 \mathrm{~m}\right)$, Montes Claros (16 $43^{\circ} \mathrm{S}$, $43^{\circ} 52^{\prime} \mathrm{W}, 647 \mathrm{~m}$ ) and Diamantina (18 $\left.{ }^{\circ} 15^{\prime} \mathrm{S}, 43^{\circ} 36^{\prime} \mathrm{W}, 1297 \mathrm{~m}\right)$. Those data were provided by the Brazilian National Institute of Meteorology (INMET). The potential evapotranspiration values (ETP) were estimated using the Hargreaves-Samani method (Samani, 2000), that had been

\footnotetext{
(Trabalho 060/2005). Recebido: 08/04/2005. Aceito para publicação: 06/10/2005.

${ }^{2}$ Researcher of the Brazilian Agriculture Research Company (Embrapa), Grape and Wine National Research Center, Tropical Viticulture Experimental Station, PO Box 241, 15700-000, Jales, SP, Brazil, E-mail address: marcoafc@enpuv.embrapa.br.

${ }^{3}$ Researcher of the Brazilian Agriculture Research Company (Embrapa), Grape and Wine National Research Center, PO Box 130, 95700-000, Bento Gonçalves, RS, Brazil E-mail address: tonietto@cnpuv.embrapa.br.
} 
chosen because it needs only temperature data and it presented good agreement with the Penman-Monteith-FAO standard method in regions with similar climate conditions (Conceição, 2003).

The Multicriteria Climatic Classification System (MCC System) was used to analyze the climatic potential to produce grapes for winemaking, that includes the Heliothermal Index (HI), the Cool Night Index (CI) and the Dryness Index (DI) (Tonietto \& Carbonneau, 2004). Tables 1, 2 and 3 show the different climatic classes for HI, CI and DI.

TABLE 1 - Class, acronym and class interval for the Heliothermal Index (HI).

\begin{tabular}{lcc}
\hline Class of viticultural climate & Acronym & Class interval $\left({ }^{\circ} \mathbf{C}\right)$ \\
\hline Very cool & $\mathrm{HI}_{-3}$ & $\leq 1500$ \\
Cool & $\mathrm{HI}_{-2}$ & $>1500 \leq 1800$ \\
Temperate & $\mathrm{HI}_{-1}$ & $>1800 \leq 2100$ \\
Temperate warm & $\mathrm{HI}_{+1}$ & $>2100 \leq 2400$ \\
Warm & $\mathrm{HI}_{+2}$ & $>2400 \leq 3000$ \\
Very warm & $\mathrm{HI}_{+3}$ & $>3000$ \\
\hline
\end{tabular}

Source: Tonietto \& Carbonneau (2004)

TABLE 2 - Class, acronym and class interval for the Cool Night Index (CI).

\begin{tabular}{ccc}
\hline Class of viticultural climate & Acronym & Class interval $\left({ }^{\circ} \mathbf{C}\right)$ \\
\hline Warm nights & $\mathrm{CI}_{-2}$ & $>18$ \\
Temperate nights & $\mathrm{CI}_{-1}$ & $>14 \leq 18$ \\
Cool nights & $\mathrm{CI}_{+1}$ & $>12 \leq 14$ \\
Very cool nights & $\mathrm{CI}_{+2}$ & $\leq 12$ \\
\hline
\end{tabular}

Source: Tonietto \& Carbonneau (2004)

TABLE 3 - Class, acronym and class interval for the Dryness Index (DI).

\begin{tabular}{lcc}
\hline Class of viticultural climate & Acronym & Class interval (mm) \\
\hline Humid & $\mathrm{DI}_{-2}$ & $>150$ \\
Sub-humid & $\mathrm{DI}_{-1}$ & $\leq 150>50$ \\
Moderately dry & $\mathrm{DI}_{+1}$ & $\leq 50>-100$ \\
Very Dry & $\mathrm{DI}_{+2}$ & $\leq-100$ \\
\hline
\end{tabular}

Source: Tonietto \& Carbonneau (2004)

The region presents a viticultural climate with intra-annual variability, making grape production possible in different periods of the year. Therefore, the climatic characterization considered two different periods: the first, from April $01^{\text {st }}$ to September $30^{\text {th }}$, was called the autumnwinter period (AW period); the other one, form October $01^{\text {st }}$ to March $31^{\text {st }}$, was named spring-summer period (SS period).

The Heliothermal Index (HI) was calculated using the following expression (Huglin, 1978):

$\left.\mathrm{HI}=\sum_{\mathrm{Mi}}^{\mathrm{Mi}} \frac{[(\mathrm{T}-10)+(\mathrm{Tmax}-10)}{2}\right] \mathrm{d}$

where "T" and "Tmax" are, respectively, the average mean and maximum monthly temperature $\left({ }^{\circ} \mathrm{C}\right)$; "Mi" and "Mf" are the initial and the final month of the period, respectively; "d" is the length of day coefficient, with value of 1.00 for latitudes below $40^{\circ}$. This index, largely used in world viticulture, provides information regarding to the level of heliothermal potential. It includes day temperature of the period when photosynthesis is active and also provides a better idea of the sugar potential than the classic temperature sums and provides, therefore, a qualitative information.

The Cool Night Index (CI) was considered as the minimum average air temperature of the last month of the period. The CI is a night coolness variable which takes into account the minimum mean night temperatures during the month when ripening usually occurs beyond the ripening period. The purpose of this index is to improve the assessment of the qualitative potentials of wine-growing regions, notably in relation to secondary metabolites (polyphenols, aromas) in grapes. The importance of that climatic factor regards to the grape and wine color and aromas.

The Dryness Index (DI) was calculated using:

$\mathrm{DI}=\sum_{\mathrm{Mi}}^{\mathrm{Mf}} \mathrm{Wo}+\mathrm{P}-\mathrm{TV}-\mathrm{Es}$

where "Wo" is the initial useful soil water reserve, which can be accessed by the roots (mm); "P" is the monthly precipitation (mm); "Tv" is the potential monthly transpiration of the vineyard (mm); "Es" is the monthly direct evaporation from the soil (mm). "Tv" was calculated using the expression:

$\mathrm{TV}=\mathrm{ETP} \mathrm{k}$

where $\mathrm{k}$ is the coefficient of radiation absorption by vine plant $(\mathrm{k}=0.1$ for the first month, 0.3 for the second month and 0.5 for the other months). "Es" was calculated using the expression:

$\mathrm{Es}=(\mathrm{ETP} / \mathrm{N})(1-\mathrm{k}) \mathrm{JPm}$

where $\mathrm{N}$ is the number of days in the month and JPm is the number of days of effective evaporation from soil per month, that was estimated dividing $\mathrm{P}$ per 5 and should be $\leq \mathrm{N}$.

The DI is measured based on the potential water balance of the soil index of Riou (Riou et al., 1994), specially developed to integrate important climate components for vineyards under precise conditions of calculation. It enables the characterization of the water component of the climate in a grape-growing region, taking into account the climatic demand of a standard vineyard, evaporation from bare soil, rainfall without deduction for surface runoff or drainage. It indicates the potential water availability in soil, related to the level of potential dryness in a region.

\section{RESULTS AND DISCUSSION}

According to the temperature values (Figure 1), it is possible to produce grape in any period along the year in the three regions in the north of Minas Gerais State. However, the low precipitation values from April to September (Figure 2) show that, in this period (AW period), the use of irrigation is necessary to avoid plant water stress.

The maximum average monthly values (Tmax) are basically the same in Montes Claros and Pirapora and vary only a few degrees along the year in the three places (Figure 1). In Pirapora, Tmax ranges from $28.2^{\circ} \mathrm{C}$, in July, to $31.7^{\circ} \mathrm{C}$, in September and October, while in Montes Claros Tmax varies between $27.1^{\circ} \mathrm{C}$ in July and $30.6^{\circ} \mathrm{C}$ in October. The Tmax values in Diamantina range from $20.9^{\circ} \mathrm{C}$, in July, to $25.3^{\circ} \mathrm{C}$, in February, showing a different behavior when compared with the two other locations. Those differences occurred because of the higher altitude value in Diamantina (nearly $1300 \mathrm{~m}$ ) when compared with Pirapora (nearly $500 \mathrm{~m}$ ) and Montes Claros (650 m). For the springsummer period (SS period) the Heliothermal Index (HI) was classified as $\mathrm{HI}_{+3}$ for Montes Claros and Pirapora, and as $\mathrm{HI}_{+1}$ for Diamantina (Table 4), representing, respectively, very warm and temperate warm viticultural climates (Table 1). For the autumn-winter period (AW period) the HI was classified as $\mathrm{HI}_{-1}$ for Diamantina and $\mathrm{HI}_{+2}$ for Montes Claros and Pirapora, corresponding to a temperate and a warm viticultural climate, respectively.

The minimum average annual temperatures (Tmin) in Pirapora, Montes Claros and Diamantina present the same behavior along the year (Figure 1). The Tmin average monthly values vary from $11.8^{\circ} \mathrm{C}$ to $17.3^{\circ} \mathrm{C}$ in Diamantina, from $12.1^{\circ} \mathrm{C}$ to $18.9^{\circ} \mathrm{C}$ in Montes Claros and from $12.2^{\circ} \mathrm{C}$ to $20.4^{\circ} \mathrm{C}$ in Pirapora. In Diamantina, the Cool Night Index (CI) was classified as $\mathrm{CI}_{-1}$, in the SS period, and as $\mathrm{CI}_{+1}$, in the AW period (Table 4), corresponding to temperate nights and to cool nights viticultural climates, respectively (Table 2). In Montes Claros and Pirapora the $\mathrm{CI}$ was classified as $\mathrm{CI}_{-2}$, in the SS period, and as $\mathrm{CI}_{-1}$, in the 


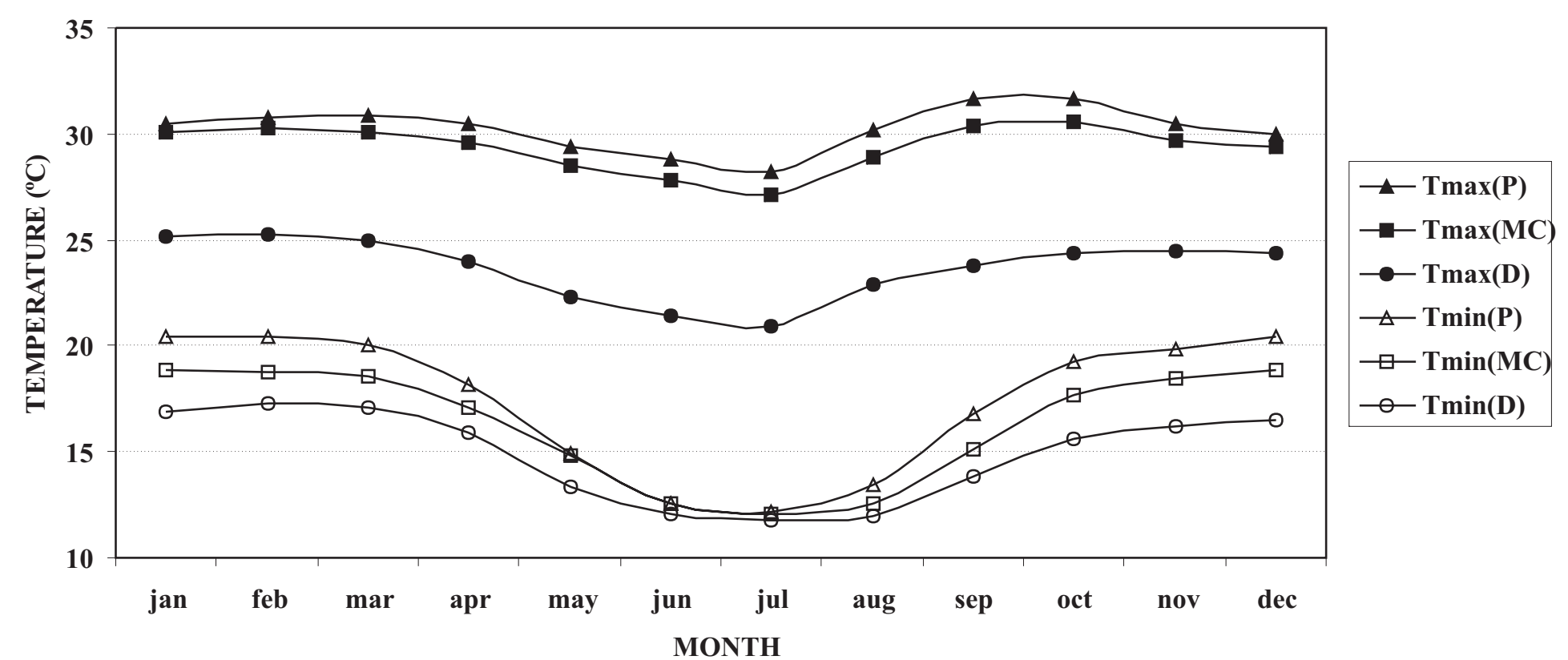

FIGURE 1 -Average maximum (Tmax) and minimum (Tmin) monthly temperatures for Pirapora (P), Montes Claros (MC) and Diamantina (D) - Based on INMET historical average data.

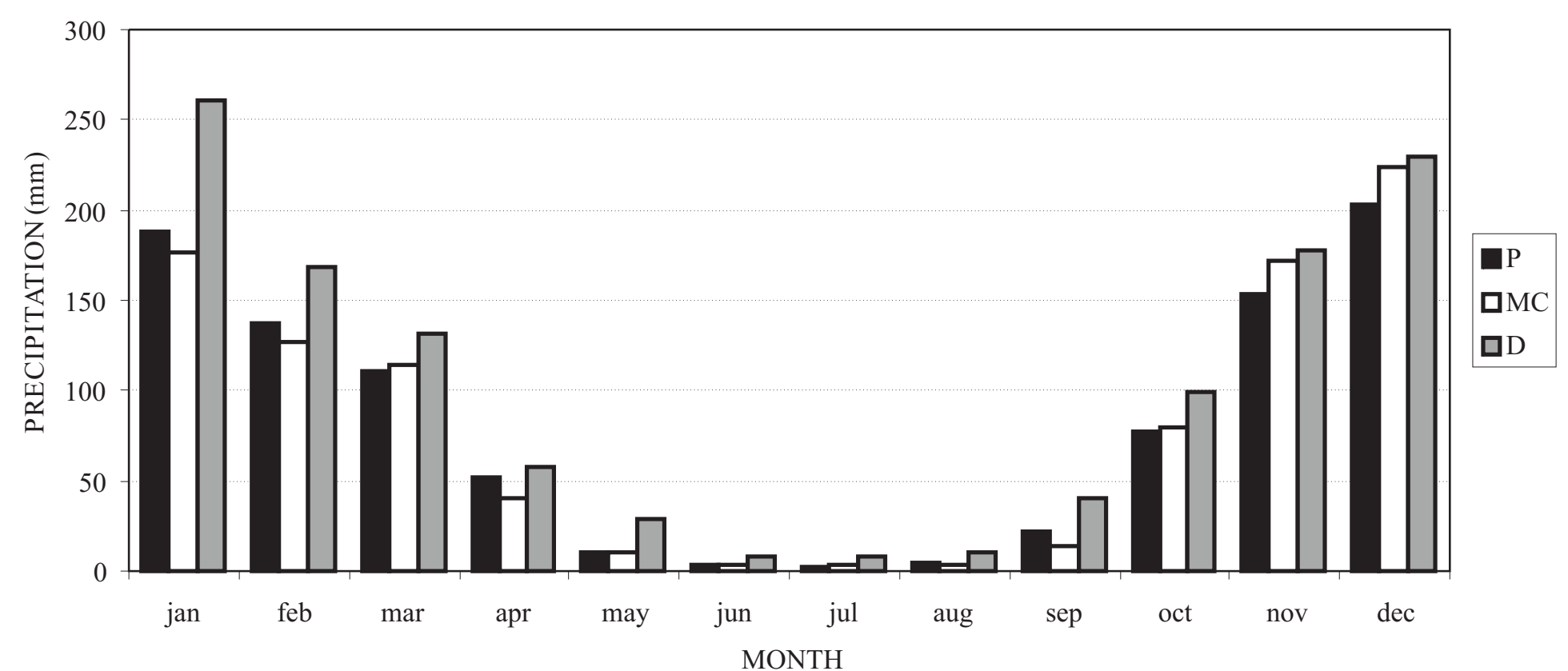

FIGURE 2 - Monthly average precipitation (P) for Pirapora (P), Montes Claros (MC) and Diamantina (D) - Based on INMET historical average data.

Pirapora the $\mathrm{CI}$ was classified as $\mathrm{CI}_{-2}$, in the $\mathrm{SS}$ period, and as $\mathrm{CI}_{-1}$, in the AW period, corresponding to warm and to temperate night viticultural climates, respectively (Table 2 ).

The Figure 2 shows the rainfall distribution in the three locations along the year. In spite of the differences between the values, the distribution behavior is the same between them, representing a humid viticultural climate $\left(\mathrm{DI}_{-2}\right)$ in the SS period. In the AW period Montes Claros and Pirapora present a moderately dry $\left(\mathrm{DI}_{+1}\right)$ viticultural climate, while Diamantina is classified as a sub-humid $\left(\mathrm{DI}_{-1}\right.$ ) climate (Tables 3 and 4). The difference of DI classification between Diamantina and the other areas in the AW period was due to the lower evapotranspiration demand in Diamantina in that period, when compared with Montes Claros and Pirapora.

The high values of temperature and precipitation make the SS period troublesome to produce grapes for wine-making in Montes Claros and Pirapora, specially because of the higher potential disease incidence in the vines and the lower quality of the grapes. The tropical Petrolina region also has elevated temperature values in this period, but the precipitation index is lower and the DI is classified as sub-humid (Tonietto \& Carbonneau, 1999). It is recommended, therefore, to conduce only a vegetative cycle in the SS months, analogous to what occurs with the table grape production in Pirapora, where the productive cycle occurs, mainly, in the AW period by using irrigation. The MCC System classification for Montes Claros and Pirapora in the AW period (Table 4) is the same of the climatic group of Murcia, Spain (Tonietto \& Carbonneau, 1999).

The SS period in Diamantina presents the same climatic classification of Serra Gaucha viticulture region, although the higher precipitation level. It is recommended, however, to conduce the grapevine production cycle in the AW period, because in this period Diamantina can be included in the same climatic group of French Bordeaux and Cognac viticulture regions, according to the MCC System (Tonietto \& Carbonneau, 1999).

The comparisons between the north region of Minas Gerais MCC System indexes with the other world viticulture regions indexes give an idea of the wine-making grape production potential. It needs to emphasize, however, that the culture development in tropical conditions presents a differentiated dynamic when comparing with temperate regions, specially in the AW period, when occurs an air temperature (T) and a solar radiation $(\mathrm{R})$ reduction in the first three months of the culture 
development cycle and a $\mathrm{T}$ and $\mathrm{R}$ rising in the last ones. In temperate climate regions the $\mathrm{T}$ and $\mathrm{R}$ values normally increase in the first five months and decrease in the last one.

TABLE 4 - Heliothermal Index (HI), Cool Night Index (CI) and Dryness Index (DI) for three locations in the north region of Minas Gerais State, considering the spring-summer (SS) and the autumn-winter $(\mathrm{AW})$ periods $^{1}$.

\begin{tabular}{lcccccccc}
\hline Location & \multicolumn{2}{c}{$\mathbf{H I}\left({ }^{\mathbf{0}} \mathbf{C}\right)$} & & \multicolumn{2}{c}{$\mathbf{C I}\left({ }^{\mathbf{0}} \mathbf{C}\right)$} & & \multicolumn{2}{c}{ DI $(\mathbf{m m})$} \\
\cline { 2 - 3 } & $\mathbf{S S}$ & $\mathbf{A W}$ & & $\mathbf{S S}$ & $\mathbf{A W}$ & & $\mathbf{S S}$ & $\mathbf{A W}$ \\
\hline Diamantina & 2319 & 1865 & & 17,1 & 13,8 & & 200 & 74 \\
& $\left(\mathrm{HI}_{+1}\right)$ & $\left(\mathrm{HI}_{-1}\right)$ & & $\left(\mathrm{CI}_{-1}\right)$ & $\left(\mathrm{CI}_{+1}\right)$ & & $\left(\mathrm{DI}_{-2}\right)$ & $\left(\mathrm{DI}_{-1}\right)$ \\
\multirow{4}{*}{ M. Claros } & 3124 & 2752 & & 18,6 & 15,1 & & 200 & -15 \\
& $\left(\mathrm{HI}_{+3}\right)$ & $\left(\mathrm{HI}_{+2}\right)$ & & $\left(\mathrm{CI}_{-2}\right)$ & $\left(\mathrm{CI}_{-1}\right)$ & & $\left(\mathrm{DI}_{-2}\right)$ & $\left(\mathrm{DI}_{+1}\right)$ \\
& 3287 & 2930 & & 20,0 & 16,8 & & 200 & -23 \\
& $\left(\mathrm{HI}_{+3}\right)$ & $\left(\mathrm{HI}_{+2}\right)$ & & $\left(\mathrm{CI}_{-2}\right)$ & $\left(\mathrm{CI}_{-1}\right)$ & & $\left(\mathrm{DI}_{-2}\right)$ & $\left(\mathrm{DI}_{+1}\right)$ \\
\hline
\end{tabular}

Based on INMET historical average data.

\section{CONCLUSIONS}

The north region of Minas Gerais State has a great climatic potential to became a grape-growing for wine-making region, specially considering the autumn-winter period.

\section{REFERENCES}

CONCEIÇÃO, M.A.F. Estimativa da evapotranspiração de referência com base na temperatura do ar para as condições do Baixo Rio Grande, SP. Revista Brasileira de Agrometeorologia, Santa Maria, v.11, n.2, p.229-236, 2003.

HUGLIN, P. Nouveau mode d'évaluation des possibilites héliothermiques d'um milieu viticole. In: SYMPOSIUM INTERNATIONAL SUR L'ECOLOGIE DE LA VIGNE, 1978, Contança. Annales... Contança: Ministère de l'Agriculture et de l'Industrie Alimentaire, 1978. p.89-98.

RIOU, C. et al. Le déterminisme climatique de la maturation du raisin: application au zonage de la teneur em sucre dans la communauté européenne. Luxemburg: Office des Publications Officielles des Communautés Européennes, 1994. 322p.

SAMANI, Z. Estimating solar radiation and evapotranspiration using minimum climatological data. Journal of Irrigation and Drainage Engineering, Reston, v.126, p.265-267, 2000.

TONIETTO, J.; CARBONNEAU, A.. Análise mundial do clima das regiões vitícolas e de sua influência sobre a tipicidade dos vinhos. In: CONGRESSO BRASILEIRO DE VITICULTURAE ENOLOGIA, 9., 1999, Bento Gonçalves. Anais... Bento Gonçalves: Embrapa Uva e Vinho, 1999. p. 75-90.

TONIETTO, J.; CARBONNEAU, A. A multicriteria climatic classification system for grape-growing regions worlwide. Agricultural and Forest Meteorology, Amsterdam, v.124, p.81-97, 2004. 